\title{
Practical Solutions to Foreign Language Training Courses Implemented Using Distance Learning Tools
}

\author{
Aleksei Yu. Alipicheva , Svetlana N. Khalevinab ${ }^{\mathrm{b}}$, Anna A. \\ Trubcheninova ${ }^{c}$ and Anna N. Fedulovac,
}

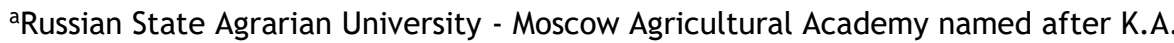

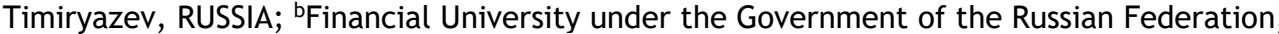
RUSSIA; 'Moscow Aviation Institute (National Research University), RUSSIA

\begin{abstract}
The present study investigates the practical solutions to foreign language training courses implemented using distance learning tools. It reveals inefficiency of existing distance learning practice as its main features and tools remain virtually untapped, neither there is an opportunity to achieve the learning outcomes specified by curriculum planning documentation. To ensure an optimal design of this study course it is necessary to consider two interdependent factors: curriculum requirements for learning outcomes (competences developed) and specific features of distance learning tools contributing to the development of these competences. On this basis, the authors design a structure of a foreign language course, providing for the development of all kinds of speech activity, as well as academic skills in the field of information search, analysis and processing, as well as strategic skills in the field of independent research and professional activities. The proposed Learning design (Conceptual map) is in many ways incomplete but the authors suppose that practicing educators may use its separate components to assist with designing and implementing effective teaching and learning activities, where the effectiveness is ultimately measured in terms of learning outcomes rather than teaching inputs. For most educators, this means using a wide range of teaching and learning approaches depending on what is most effective in their context. And to the extent that sharing learning designs helps educators to adopt new, effective teaching and learning methods, then ultimately student learning will improve.
\end{abstract}

KEYWORDS

Foreign language training courses, distance learning, learning design, design-based research
ARTICLE HISTORY

Received 11 June 2016

Revised 14 October 2016 Accepted 26 October 2016

\section{CORRESPONDENCE A. Yu. Alipichev $\triangle$ al_new2003@mail.ru}

(c) 2017 A. Yu. Alipichev et al.

Open Access terms of the Creative Commons Attribution 4.0 International License apply. The license permits unrestricted use, distribution, and reproduction in any medium, on the condition that users give exact credit to the original author(s) and the source, provide a link to the Creative Commons license, and indicate if they made any changes. (http://creativecommons.org/licenses/by/4.0/) 


\section{Introduction}

Urgency of the problem

Modernization of Russian education, the trends of the international educational integration put forward before the Russian higher education new goals, the solution of which are to be seen in the deep qualitative transformations (Kalimullin \& Masalimova, 2016).

Modern education faces many acute challenges. New information technologies have an impact on today's educational system by providing great opportunities for optimization and improvement of the quality of learning process (Fedulova, 2015). Learners widely using digital technologies and requiring some strategical competencies to survive in the real-life environment are changing their expectations towards the contents of study courses. Teachers also face many changes - "such as expectations of adopting innovative teaching approaches, alignment of teaching to external standards, growing requirements for professional development and difficulties in balancing a complex range of demands from different stakeholders" (Dalziel, 2016).

Modern scientific and technological progress, the development level of the global Internet entails dramatic changes of means and technologies of educational activity, appearance of considerably new approaches to foreign language learning for professional purposes based on a wide use of information and communication technologies (Fominykh et al., 2016).

Globalization and integration process opens new opportunities, types and forms of communication, the existence of which is impossible without mutual understanding between different cultures (Vasbieva \& Kalugina, 2016).

With the advancement in communication and network technologies, the teaching environment has extended and learning solutions have emerged in order to provide meaningful learning experiences for learners in academic settings (Vasbieva et al., 2016).

In the context of these changes, effective teaching and learning beyond the classroom turns out to be one of the key issues.

Currently, a considerable number of Russian Universities are developing various distance learning programs, and foreign language courses are no exception. Therefore, in a number of high institutions the tendency of decrease in lecture hours is observed, up to full reduction of some disciplines or their replacement with video courses (Frolova et al., 2016). Numerous higher education establishments offer training programs, particularly, for MSc students, implemented in a distance format using distance learning tools. However, the content selection algorithm and methodical organization of the language training have not been worked out completely yet. In practice, the study platforms often only contain control tasks (texts, tests, exercises) that students may download, perform, and then send to tutors for checking, at best, via e-mail. Also the sites may provide access to various basic and supplementary training materials accompanied with instructions what exactly and in what amount is to be examined. It should be noted that distance learning will not work if the university does not have a well-constructed electronic learning environment including computersupported collaborative learning, electronic learning resources and learning administration system (Borisova et al., 2016).

Our point is that the existing practice cannot be considered efficient, in fact, the main features of distance learning and its tools remain virtually untapped, neither there 
is an opportunity to achieve the learning outcomes specified by curriculum planning documentation. The existing "distance learning" practice simply reduces to the replacement of conventional post services as an essential feature of the traditional correspondence learning with e-mail, and the substitution of traditional libraries with electronic ones. So, educational practices should be re-defined, which will enable students to access and manage their own learning, with the guidance and pedagogical support of the teachers (Vasbieva, 2016).

Therefore, to ensure an optimal design of a study course implemented using distance learning tools, it is necessary to consider two interdependent factors:

1) curriculum requirements for learning outcomes (competences developed)

2) specific features of distance learning tools contributing to the development of these competences.

On this basis, we can design a structure of a foreign language course, providing for the development of all kinds of speech activity, as well as academic skills in the field of information search, analysis and processing, as well as strategic skills in the field of independent research and professional activities.

\section{Literature Review}

The idea for this study developed from research conducted by S. Barab \& K. Squire (2004), P. Cobb et al. (2004), M. Bower (2016), J. Dalziel (2016), etc.

Design-based research is a methodology advocated by many researchers to address the complicated and integral nature of existing learning design problems (Barab \& Squire, 2004; Cobb et al., 2004). "While design-based research is not strictly considered to be a learning design concept or practice, its typical focus on improving learning and teaching in technology enabled environments means that it is often used in learning design contexts" (Bower, 2016).

A learning design is defined in methodological literature as "a sequence of teaching and learning activities, a plan for potential activities with learners, which is to be distinguished from a particular implementation of this plan with a particular group of learners" (Bower, 2016).

An 'effective' learning design description was identified by Britain (2004); Falconer and Littlejohn (2006), etc.

For university educators, designing effective learning experiences requires them to draw together their specialist domain expertise with appropriate teaching strategies, while integrating the range of digital technologies that are now commonplace in higher education. This represents a significant challenge for even the most experienced university educators

Learning Design has emerged as a particular branch of educational research and development that seeks to understand and support the design processes inherent in teaching (Bennett et al., 2016).

This premise for design support has generated a multitude of different approaches, contributing to different aspects of Learning Design. Some have focused on developing tools to support design by helping educators think about and make decisions about their design ideas (Laurillard et al., 2013; Conole, 2013) for a review of Learning Design tools). Others have sought to support the shar-ing of 'good' design ideas through repositories or online networking tools (e.g., online community sharing, and collections of examples or cases. These efforts have been complemented by investigations into different ways in which designs can been effectively represented (Agostinho et al., 2013; McAndrew \& Goodyear, 2013). 
Students should get a fairly complete and adequate understanding of the structure and specificity of their future professional activity and demonstrate profound interest in it, as well as the highly developed professional thinking. This is impossible without the correspondence of the teaching content with the requirements made for practitioners (Kuznetsov, 2014). Moreover, the qualitative training of specialists should coincide to the international and national standards (Zhyltyrova et al., 2016).

\section{Methodology}

The study has been undertaken as part of the methodology of pedagogy, methodology, and fundamental pedagogical works considering intercultural communication in terms of various aspects.

\section{Results and Discussion}

The purpose of this research paper was to implement an analysis of educational standards for MSc training in "Design of Educational Systems and Technologies" that would show the next set of skills to be formed by means of the "Foreign Language" course.

Table 1. Learning outcomes developed by means of the "Foreign language" course (MSc in Pedagogy - Design of Educational Systems and Technologies)

\begin{tabular}{|c|c|}
\hline Competency & Developed skills \\
\hline $\begin{array}{l}\text { ability and readiness to freely } \\
\text { use Russian and a foreign } \\
\text { language as a means of } \\
\text { professional communication }\end{array}$ & $\begin{array}{l}\text { - use a foreign language as a means of scientific, } \\
\text { professional and business communication for more } \\
\text { effective performance of one's professional duties, } \\
\text { personal and professional development (further training) }\end{array}$ \\
\hline $\begin{array}{l}\text { ability and readiness to } \\
\text { deeply comprehend and } \\
\text { formulate diagnostic } \\
\text { solutions to professional and } \\
\text { pedagogical problems }\end{array}$ & $\begin{array}{l}\text { perceive, analyze and synthesize information in } \\
\text { tackling professional and pedagogical problems, } \\
\text { especially using a foreign language, setting objectives } \\
\text { and identifying ways of their achieving; } \\
\text { - use in practice the basic ways and means to acquire } \\
\text { and utilize specific knowledge and relevant skills in the } \\
\text { field of professional and educational activities }\end{array}$ \\
\hline $\begin{array}{l}\text { ability and readiness to } \\
\text { present their scientific } \\
\text { activity results }\end{array}$ & $\begin{array}{l}\text { - perform written tasks (translations, essays, abstracts, } \\
\text { summaries, reports, presentations, etc.) in accordance } \\
\text { with the formal requirements to their content and } \\
\text { structure; } \\
\text { - make self-presentations, present one's goals and } \\
\text { intentions, make a report, engage in conversation } \\
\text { applying relevant communicative functions depending on } \\
\text { the situation of communication; } \\
\text { - present one's research results in the form of reports, } \\
\text { analytical reviews, scientific publications and } \\
\text { presentations at professional and scientific discussions }\end{array}$ \\
\hline
\end{tabular}

Thus, with respect to the considered field of study the "Foreign Language" course should be aimed at improving the language skills for academic work and practical implementation of a foreign language in the following areas and situations of professional and everyday communication:

- doing research with the information search in foreign-language sources;

- doing business and going on scientific trips abroad, arranging of travel, accommodation and cultural programmes; 
- making presentations at scientific conferences, round tables and workshops, establishing professional and scientific contacts with foreign colleagues.

Therefore, special attention should be paid to the acquisition of skills to extract information from professionally oriented texts and adequately express it using the means of another language, orally or in writing, expand professional linguistic and cultural horizons, as well as the formation of respectful attitude to professional and cultural values of other countries.

So the following activities can be considered as priority aspects of training:

- analysis of general and specific vocabulary and verbal clichés in the context of domains of professional and everyday communication;

- analysis of the content frames (scenarios) in the context of areas and situations of professional and everyday communication;

- mastering different reading strategies and techniques in respect to some relevant foreign language sources;

- production of different types of 'processed' texts based on the analysis of original foreign-language texts (abstracts, summaries, topical reviews);

- presentation of the results of dealing with foreign-language sources in tackling professional communicative tasks (in the form of PP- presentation);

- acquisition of applied knowledge and skills in the field of professional and business communication (Alipichev, 2015).

The analysis of distance learning courses of foreign languages implemented today reveals that the basic distant learning tools are presented by the following services (Alipichev, 2016):

- information resource as a source of new, scientific, didactic and professionally relevant information;

- task as a means of assignment which requires answering some questions and solving some problem situations (translation of a text, performance of lexical and grammatical exercises, case solving based on the analysis of a specific sequence of actions or specific situation, listening to an audio file (aural comprehension) and the performance of relevant tasks);

- forum (discussion panel) and chat as forms of asynchronous and synchronous exchange of information (to discuss controversial issues or solutions to problematic situations, difficulties of the translation of certain terms, quasi-professional discussion in a foreign language), as well as the working out of wiki-documents (joint discussion of problems and the development of common instruments reflecting their solutions);

- test to verify the formation of target knowledge and skills (lexical and grammatical tasks for understanding the text ideas and the translation accuracy);

- webinar as a form of oral communication and presentation of research results in real time.

It is important to understand what types of training activities must be provided for each block of training material. To do this, course designers should elaborate a general scenario of a distance course - make its conceptual map (thematic plan) and identify ways of working with the material.

Table 2. Learning design (Conceptual map) of a 'Foreign Language" course Study materials Study activities 


•textual material (about the topic):
"Intercultural communication in the
modern world";
"Cultural stereotypes", "Interpersonal
relations in intercultural context",
"Status of professionals", "Learning
strategies"; "Time management in
academic environment", "Academic
dress code", etc.
dress code", etc.
- translation of text materials and abstracting

- compilation of topical vocabularies (glossaries)

- writing essays basing on the studied text materials ("Current incentives for personal development", "Performance criteria of professional activity"; "The role of the traditional test in ensuring the quality of education"; "The need for censorship these days")

- test activities to check understanding of the text

1) provide answers to the given questions multiple choice;

2) search in a foreign-language text for specific words (expressions) equivalents to the provided Russian ones (comparison);

3) stating the truth of statements (multiple choice);

4) drawing up the text plan (ordering abstracts / subtitles);

5) choosing the correct translation (multiple choice);

6) the correlation of causes and effects;

7) selecting a predetermined word translation in a definite context (multiple choice)

- sample lexical-and grammatical 1) insert the appropriate words in sentences exercises (multiple choice).

2) correlating words (expressions) and their translation;

3) opening the brackets with the correct use of grammatical forms (translation).

- forum / chat discussions $\quad$ - sample topics for discussion

"The success of intercultural communication imitation and preservation of identity?";

'"Code' of intercultural behaviour";

"More effective learning strategy - independent or team-based?";

"Moral and ethical standards in the academic environment";

"Norms and rules of etiquette and the problems of plagiarism"

- $\quad$ work with audio texts

- filling in missing words

- ordering statements in a logical sequence

- completing the statements (sense prediction)

\begin{tabular}{|c|c|}
\hline Theoretical module & - lecture (review) materials \\
\hline $\begin{array}{l}\text { - vocabulary of a particular sphere, } \\
\text { general scientific and highly specialized } \\
\text { vocabulary, a bilingual glossary } \\
\text { - information search technology and } \\
\text { reading strategies } \\
\text { - plan, summary and abstract of a text } \\
\text { - etiquette rules applied in discussing } \\
\text { of research ideas }\end{array}$ & $\begin{array}{l}\text { - written answers to questions; } \\
\text { - test to check the understanding of the } \\
\text { material } \\
\text { - group work with the publication of the forum } \\
\text { report or the wiki-document (thematic } \\
\text { vocabulary, searching foreign language sources } \\
\text { on the proposed theme using keywords, } \\
\text { summarizing textual information, making } \\
\text { recommendations for intercultural interaction } \\
\text { with the representatives of a certain nation, the } \\
\text { instruction on preparation and making academic } \\
\text { presentations) }\end{array}$ \\
\hline
\end{tabular}




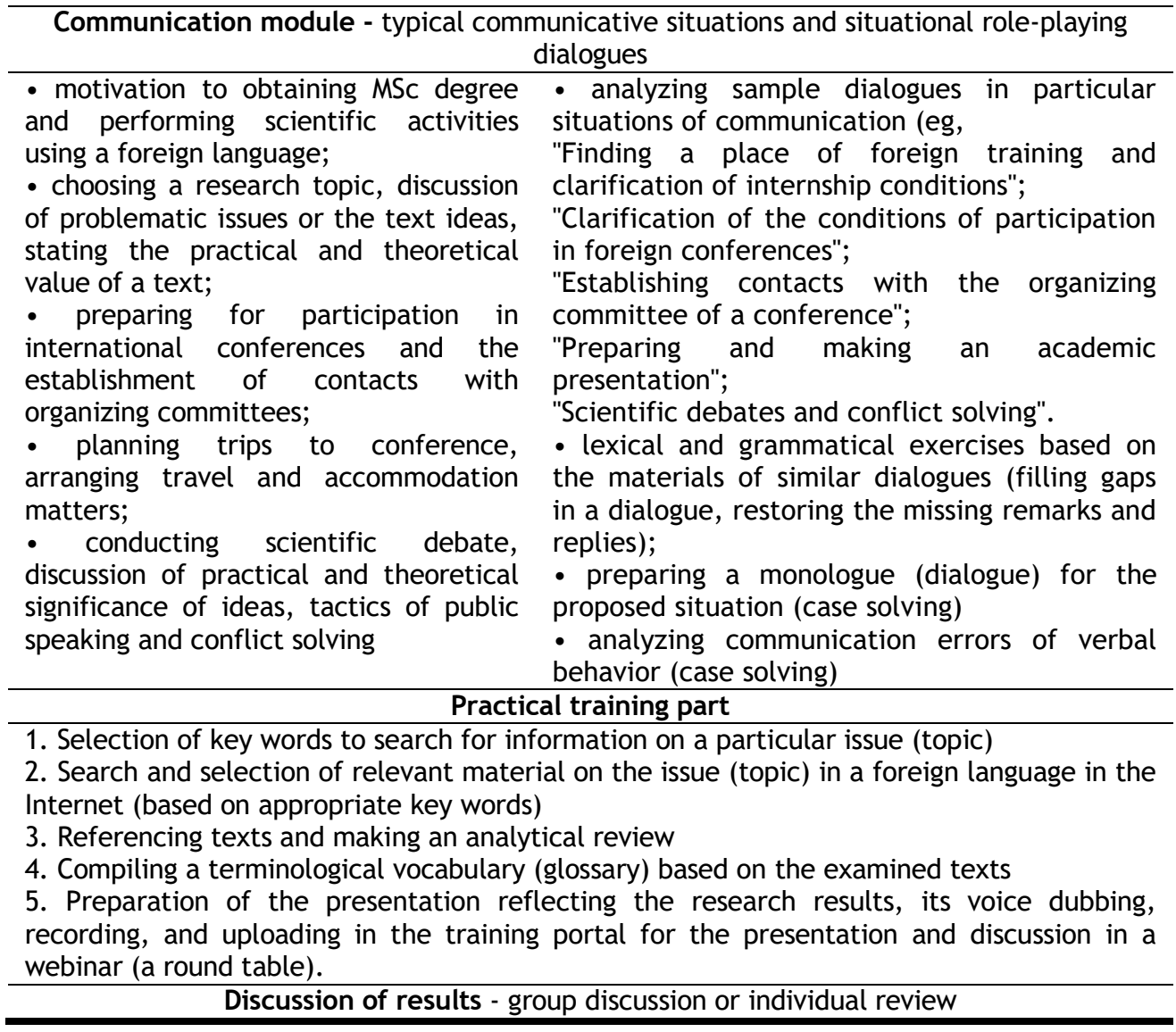

\section{Conclusion}

The proposed Learning design (Conceptual map) is in many ways incomplete but we suppose that practicing educators may use its separate components "to assist with designing and implementing effective teaching and learning activities, where the effectiveness is ultimately measured in terms of learning outcomes rather than teaching inputs. For most educators, this means using a wide range of teaching and learning approaches depending on what is most effective in their context. And to the extent that sharing learning designs helps educators to adopt new, effective teaching and learning methods, then ultimately student learning will improve" (Dalziel, 2016).

However, practical approbation of a sample course has shown a number of specific problems, the ways of overcoming them are yet to be found, namely:

1) the lack of direct interpersonal interaction between the teacher and students, the prevalence of mediated communication in a written form (commenting on assignments, questions and answers in a forum or chat format, e-mail correspondence), which makes certain psychological difficulties and often forms a wrong profile of the teacher in the students' eyes (too much demanding, concentrated only on his/her subject, biased in estimates), as well as vice versa (students may seem irresponsible, unreliable or requiring special attention). Part of the problems can be solved by organizing webinars that allow to communicate in a "live" format, but alongside with technical difficulties, is not always possible to appoint time convenient to all participants; 
2) different start level of knowledge and skills of students and problems in differentiating tasks provided by the course content. Again, despite the fact that the task is not to suppress the desire to learn of "weak" students while allowing "strong" ones to further develop their skills, the best option is the differentiation of tasks into compulsory and optional that can be performed at the students' discretion only;

3) difficulties in ensuring totally independent work of students, because they perform their assignments in a remote and predominantly asynchronous mode. In fact, there is no guarantee that the tasks are done entirely independently without resorting to a third party assistance. This problem can be solved with the help of webinars, but they do help to completely control all kinds of speech activity to achieve the goal prescribed in the course learning outcomes;

4) the complexity of ensuring scheduled studying of the course materials, as the block approach is not very appropriate and productive in the study of a foreign language, so courses are typically extended for the whole semester. As our experience shows, about $30-40 \%$ of the students do not adhere to the planned schedule of work, which is caused, first of all, with a necessity to concentrate on several subjects simultaneously.

5) due to the previous fact it is still not entirely clear how to ensure adequate evaluation of the students' outcomes. There is a need of a system of assessment which could help teachers to progress and monitor language development. The processes, which take place in the educational industry lately, require strengthening of efficiency of control system after educational-educative activity of students (Dinayeva et al., 2016). Nowadays, teachers are given too much freedom which causes a lack of systematization or direction in their work (Birova, Klimova, \& Kalugina, 2016). On the one hand, it is possible to take into account the timeliness of task submission and the consequent possibility of their self-revision and mistake correction, while the late task submission leads to their assessment only "by their merits", thus eliminating the possibility of improving the results. However, it so happens that the late task submission can be accompanied with a high degree of responsibility and show obvious progress in learning. In any case, without personal interaction between teachers and students, any 'lowered' evaluation by the teacher may be perceived by students as injustice and partiality in the assessment, which may decrease their further motivation to work with maximum efficiency.

Thus, with many positive aspects and sufficiently broad potential of foreign language course implemented in a distance learning format, there are still a number of problems both inherent to any curriculum, and specific for a foreign language course, the solution of which is to reflect and analyze experience in designing similar courses including the foreign one.

\section{Disclosure statement}

No potential conflict of interest was reported by the authors.

\section{Notes on contributors}

Aleksei Yu. Alipichev is PhD, Associate Professor of Russian State Agrarian University Moscow Agricultural Academy named after K.A. Timiryazev, Moscow, Russia.

Svetlana N. Khalevina is $\mathrm{PhD}$, Associate Professor of Financial University under the Government of the Russian Federation, Moscow, Russia.

Anna A. Trubcheninova is PhD, Associate Professor of Moscow Aviation Institute (National Research University), Moscow, Russia. 
Anna N. Fedulova is PhD, Associate Professor of Moscow Aviation Institute (National Research University), Moscow, Russia.

\section{References}

Agostinho, S., Bennett, S., Lockyer, L., Jones, J. \& Harper, B. (2013). Learning designs as a stimulus and support for teachers' design practices. In: Beetham, H. and Sharpe, R (Eds.) Rethinking pedagogy for a Digital Age: Designing and delivering e-learning (2nd Edition). New York: Routledge, 119-132.

Alipichev, A.Yu. (2015). The specificity and implementation prospects of modular courses in the context of professionally focused foreign language training in universities. Proceedings of the International Scientific Conference "Current problems of linguistics and linguistic education and their solutions in nonlinguistic universities, 6(32), 145-151.

Alipichev, A.Yu. (2016). Viable solutions to problems of professionally oriented foreign language distance training in universities. Communication in today's multicultural world: nationally cultural specificity of the discourse construction. Moscow: Pearson, 231-242.

Barab, S. \& Squire, K. (2004). Design-Based Research: Putting a Stake in the Ground. The Journal of the Learning Sciences, 13(1), 1-14.

Bennett, S. et al (2016). Investigating University Educators' Design Thinking and the Implications for Design Support Tools. Journal of Interactive Media in Education, 9, 1-10.

Birova, J., Klimova, I.I. \& Kalugina, O.A. (2016). Some Critics on Language Education Assessment. IEJMEMathematics Education 11(7), 2470-2482

Borisova, O.V., Vasbieva, D.G., Malykh, N.I., Vasnev, S.A. \& Bírová, J. (2016). Problem of Using Innovative Teaching Methods for Distance Learning Students. IEJME-Mathematics Education, 11(5), 1175-1184.

Bower, M. (2016). A Framework for Adaptive Learning Design in a Web-Conferencing Environment. Journal of Interactive Media in Education, 11, 1-21.

Britain, S. (2004). A review of learning design: Concept, specifications and tools. Retrieved from: http://www.jisc.ac.uk/ uploaded_documents/ACF83C.doc.

Cobb, P, Confrey, J, diSessa, A, Lehrer, R. \& Schauble, L. (2004). Design Experiments in Educational Research. Educational Researcher, 32(1), 9-13.

Conole, G. (2013). Tools and resources to guide practice. In: Beetham, H. and Sharpe, R. (Eds.) Rethinking Pedagogy for a digital age: Designing for 21st century learning. New York: Routledge, 78-101.

Dalziel, J. (2016). The Larnaca Declaration on Learning Design. Journal of Interactive Media in Education, 7, 124.

Dinayeva, B.B., Sapina, S.M., Utanova, A.K. \& Aitova, N.N. (2016). Application Features of Language Acquisition Assessment System in Kazakhstan: KAZTEST. International Journal of Environmental and Science Education, 11(18), 11351-11360.

Falconer, I. \& Littlejohn, A. (2006) Mod4L Report: Case Studies, Exemplars and Learning Designs. Retrieved from: http://mod4l.com/tiki-download_file. php?fileId=2

Fedulova A.N. (2015). Computer technologies in teaching translators in engineering aerospace. Edited volume of teaching staff and students of Foreign language Department of MAI-NRU. Moscow, 227-232.

Fominykh, N., Barsova, O., Zarudnaya, M. \& Kolomiytseva, N. (2016). Approaches to Prospective Economists Professional Foreign Language Training in Computer Orientated Language Learning Environment. International Journal of Environmental and Science Education, 11(18), 12067-12083.

Frolova, V.B., Kalugina, O.A., Artamonova, L.S. \& Boykov, A.I. (2016). Studying the Practice of Performance Assessment and Rating System Implementation in Higher Institutions. IEJME-Mathematics Education, 11(5), 1185-1193.

Kalimullin, A.M. \& Masalimova, A.R. (2016). Editorial: Actual Issues of National Education: Theory and Practice. IEJME-Mathematics Education, 11(1), 1-2.

Kuznetsov, A.N. (2014). Competence capacity of a subject course (as exemplified by the "Foreign Language" educational domain). Monograph. Moscow: MSAU, 47-48.

Laurillard, D., Charlton, P., Craft, B., Dimakopoulos, D., Ljubojevic, D., Magoulas, G., Masterman, E., Pujadas, R., Whitley, E.A. \& Whittlestone, K. (2013). A constructionist learning environment for teachers to model learning designs. Journal of Computer Assisted Learning, 29, 15-30.

McAndrew, P. \& Goodyear, P. (2013). Representing practitioner experiences through learning designs and pat-terns. In Beetham, $\mathrm{H}$ and Sharpe, R (Eds.) Rethinking Pedagogy for a digital age: Designing for 21st century learning. New York: Routledge, 133-144.

Vasbieva, D.G. \& Kalugina, O.A. (2016). An Analysis of Students' Intercultural Competence Levels in a NonLinguistic Higher School. XLinguae, 9(3), 58-69. 
Vasbieva, D.G. Klimova, I.I., Agibalova, E.L., Karzhanova, N.V. \& Bírová, J. (2016). Enhancement of Students' Vocabulary Learning Through a Blended Learning Approach. IEJME-Mathematics Education, 11(5), 1195-1203.

Vasbieva, D.G. (2016). Mobility in learning: electronic language learning on smartphones. Proceedings of the International Scientific Conference "Pearson Solutions for Enhanced Students' and Teachers' Academic Mobılity". Moscow: Pearson, 44-49.

Zhyltyrova, Z., Makasheva, A., Yersultanova, G. \& Kydyrbay, K. (2016). Modern Methods in Training Professional Foreign Language for Students Majoring in Agriculture. International Journal of Environmental and Science Education, 11(18), 12289-12297. 